\title{
Molecular Genetic Etiology of Prostate Cancer
}

\author{
Vaijayanti V. Pethe ${ }^{1,2}$ and Bharati Bapat ${ }^{*}, 1,2,3$
}

${ }^{I}$ Samuel Lunenfeld Research Institute and ${ }^{2}$ Department of Pathology and Laboratory Medicine, Mount Sinai Hospital, Toronto, Canada

${ }^{3}$ Department of Laboratory Medicine and Pathobiology, University of Toronto, Toronto, Ontario, Canada

\begin{abstract}
Prostate Cancer (PCa) is the most frequently diagnosed non-skin cancer and second leading cause of cancer deaths after lung cancer in the western industrialized countries. It varies widely by geographic location and ethnicity. It is clinically heterogeneous, complex and indeed a multi-factorial disease. While the majority of PCa is sporadic, as much as up to $40 \%$ of the cases are associated with some form of genetic susceptibility. It is clear today that etiology of PCa involves several genetic loci with no single major gene accounting for a large proportion of susceptibility to the disease. In particular, allelic variations in four genes, namely RNASEL (1q25), MSR1 (8p22), ELAC2 (17p11) and EphB2 (1p36) have been shown to be associated with increased susceptibility to PCa. Also, tumors harboring mutations in these genes present with more aggressive clinical features and poor outcome. Recently, novel genetic alterations in prostate cancer patients have been identified - these include gene fusions involving the prostate-specific gene transmembrane protease, serine 2 (TMPRSS2) and members of the erythroblastosis virus E26 transforming sequence (ETS) family of transcription factors. This predominant molecular subtype is considered to be an early event in $\mathrm{PCa}$, and emerging evidence demonstrates its potential in prostate cancer detection, stratification and treatment. In addition to gene fusions, there is compelling evidence demonstrating 8q24 region as a prostate cancer susceptibility locus and markers at this locus are statistically significantly associated with an increased PCa risk in different ethnic groups. Genotyping of SNPs / markers in a predefined 8 q24 region as well as genome-wide association studies have implicated several polymorphisms ( rs7008482, rs1447295, rs16901979, rs698367) in this region as risk factors for PCa. In additions to genetic alterations, frequent epigenetic aberrations such as DNA hypermethylation of tumor suppressor genes has been observed in PCa affecting the expression and function of a battery of genes leading to tumorigenesis, tumor progression and metastasis. In this review, we highlight some of the recent advances in molecular genetic etiology of PCa including promising candidate hereditary PCa susceptibility genes, novel gene fusions in acquired $\mathrm{PCa}, 8 \mathrm{q} 24$ susceptibility locus, as well as examine current literature regarding epigenetic changes leading to prostate cancer development and progression.
\end{abstract}

\section{INTRODUCTION}

Prostate Cancer $(\mathrm{PCa})$ is the most frequently diagnosed non-skin cancer and second leading cause of cancer deaths after lung cancer in the western industrialized countries [1, 2]. It is predominantly a disease of elderly men, its incidence increasing steeply in the $7^{\text {th }}$ decade of life. An estimated $40 \%$ of men over 50 years of age have slow growing and welldifferentiated prostate cancer that can be histologically diagnosed. The incidence of prostate cancer varies widely by geographic location, and race/ ethnic background. The highest rates are reported in the US, Canada, Sweden, Australia and France. Global incidence patterns indicate that European countries have intermediate rates and Asian countries have lowest rates [3]. When stratified by ethnicity, AfricanAmericans have higher incidence ( $40 \%$ of all PCa cases) and mortality rates compared to other ethnic groups in the US [4, 5] The traditional and widespread use of Prostate Specific Antigen (PSA) and digital rectal exam for PCa screening has resulted in earlier disease detection in the last decade.

*Address correspondence to this author at the Samuel Lunenfeld Research Institute, Mount Sinai Hospital, R No. L6-304 B, 60 Murray St., Toronto, Ontario, Canada M5T 3L9; Tel: (416) 586-4800, Ext 5175; Fax: (416) 3612655; E-mail: bapat@mshri.on.ca
Treatment options including radical prostactomy, external beam radiation and brachytherapy are being increasingly used to control localized disease. Despite these attempts, $\mathrm{PCa}$ continues to be a significant health problem in most western countries. The treatment of PCa is difficult, in that only a small proportion of men diagnosed will have the aggressive form of the disease. Prostate tumors can be very slow growing and as such many men die with and not because of their PCa [6]. Prostate cancer is a complex and multifactorial disease and factors such as lifestyle, environment, hormones, and occupation have long been recognized as contributors of the disease [7]. Risk factors for overall incidence of $\mathrm{PCa}$ include increasing age, body-mass index (BMI), cigarette smoking, a lack of physical activity, ethnic background (e.g. African ancestry), and family history of $\mathrm{PCa}[8,9]$. Role of different dietary factors in PCa development has been studied; these include -supplementation with minerals like Calcium, Selenium, Zinc, Vitamins such as A, $\mathrm{D}$, E; intake of soy, green tea, tomato-rich products (lycopene) and alpha-lenoleic acid, as well as dietary lipids [913]. Diet that includes fruits, vegetables (tomatoes, legumes), selenium, vitamin $\mathrm{E}$ and $\mathrm{D}$ have been suggested to decrease the risk of PCa. Moreover, there is emerging evidence that low-grade infection may have a role in prostate cancer development [14]. Predisposition to prostate cancer is 
most likely caused by altered expression of some known and novel genes, and different models of Mendelian inheritance of germline mutations in candidate susceptibility genes [1520]. The Androgen Receptor (AR) gene has also been implicated as a dominant oncogene in a subset of PCa cases; phosphorylation, somatic alterations, polymorphisms, amplification and over expression of Androgen Receptor are detected in PCa cases that progress despite hormonal treatment [21-25]. In addition to genetic mechanisms, epigenetic changes leading to transcriptional inactivation and loss of expression of tumor suppressor genes significantly contribute to PCa progression [26-28].

\section{GENETIC SUSCEPTIBILITY TO PROSTATE CAN- CER}

It is estimated that one in six men will have $\mathrm{PCa}$ in their life time and the risk of death due to metastatic disease is estimated to be $3-4 \%$ [16]. The majority of PCa is sporadic and displays an age-related increase in prevalence. It has been estimated that as much as $40 \%$ of PCa cases are likely to be associated with some form of genetic susceptibility. The underlying genetic factors include contribution of rare highly penetrant alleles, more frequently occurring weakly penetrant alleles, and gene-gene interactions. The terms "familial" and "hereditary" imply increased risk due to genetic susceptibility but are not synonymous. A diagnosis of hereditary prostate cancer includes early age of onset $(<55$ years of age) and having three or more family members diagnosed with $\mathrm{PCa}$, consistent with the inheritance of a highly penetrant rare susceptibility gene. Familial PCa cases show evidence of aggregation of $\mathrm{PCa}$, but not necessarily inherited in Mendelian fashion.

\section{Familial Prostate Cancer}

Familial aggregation of $\mathrm{PCa}$ has been recognized since 1958. Familial prostate cancer, which accounts for up to $20 \%$ of all cases of the disease in general population, refers to the occurrence of multiple cases (clustering) of $\mathrm{PCa}$ within a family. It is commonly defined as a family in which there are two first-degree (father, brother, son) relatives or one first-degree and at least two second-degree (grandfather, uncle, nephew) relatives with $\mathrm{PCa}$. This clustering may be due to shared environment or chance occurrence given high frequency of $\mathrm{PCa}$ in general population, or may be due to genetic susceptibility. Populations of different origins including US Caucasian, Canadian, European, Asian, AfricanAmericans exhibit this type of clustering [29-34]. Evidence also indicates that the risk of PCa increases proportionally to the number of relatives affected, the degree of relationship to the proband and is inversely related to the age at diagnosis of PCa. Epidemiologic studies employing different study designs and/or populations suggest that a family history of $\mathrm{PCa}$ that includes an affected father or brother is associated with at least a 2-fold increase in the disease risk among the relatives [31]. Men with 3 or more first -degree relatives with $\mathrm{PCa}$ are at a 5 to 11 -fold increased risk of disease, than men without family history [31, 35]. Hemminki et al. (2008) [36] recently studied a total of 34 cancer sites among 205, 638 cases from the Swedish Cancer Registry, and reported that PCa showed the highest familial proportion $(20.15 \%)$, followed by breast (13.8\%) and colon $(12.8 \%)$ cancer. A recent study involving a cohort of 179 patients from Quebec, Can- ada, reported familial clustering, defined as having at least one affected relative in the family, in $25 \%$ of cases [34].

\section{Hereditary Prostate Cancer}

Hereditary prostate cancer accounts for $5-10 \%$ of all $\mathrm{PCa}$ [37]. It is marked by a pattern consistent with passage of a rare highly penetrant susceptibility gene via Mendelian inheritance as an autosomal dominant susceptibility trait [20]. Hereditary PCa families are characterized by at least one of the following criteria, originally defined by Carter et al. 1993 [37]. These include: 3 or more first-degree relatives with $\mathrm{PCa}$, three successive generations with $\mathrm{PCa}$ (either through paternal or maternal lineage), and two siblings with prostate cancer diagnosed at a relatively young age $(<55$ $\mathrm{y} / \mathrm{o})$. Although inherited forms of PCa tend to develop at an earlier age compared to sporadic cases, the differences in terms of biological potential for PCa progression, biochemical recurrence, pathological characteristics of tumors between inherited and sporadic forms of the disease are less evident [37-39]. The genetics of hereditary prostate cancer is complex and several genes have been proposed as susceptibility factors in this syndrome. In the following section, we briefly describe promising candidate hereditary PCa susceptibility genes. We also summarize candidate genes that are known to alter overall PCa risk in different ethnic populations (Table 1).

\section{PROSTATE CANCER SUSCEPTIBILITY GENES}

Over the past decade, there have been many published studies suggesting linkage of PCa susceptibility to different chromosomal regions including $3 \mathrm{p}, 5 \mathrm{q}, 8 \mathrm{q}, 13 \mathrm{q}, 15$ and $\mathrm{X}$ [40]. Predisposition to $\mathrm{PCa}$ is probably polygenic, which can be explained by different models of Mendelian inheritance or incomplete penetrance. Segregation analyses also support autosomal recessive or X-linked, as well as multifactorial mode of inheritance. It is clear that PCa etiology involves several genetic loci with no major or a single gene accounting for a large proportion of susceptibility to the disease. However, germline mutations have been found in a few candidate genes for hereditary prostate cancer. These include RNASEL at $1 \mathrm{q} 25$, MSR 1 at $8 \mathrm{p} 22, E L A C 2$ at $17 \mathrm{p} 11$ and more recently $E p h B 2$ at $1 \mathrm{p} 36$. The frequency of nonsense and missense mutations within these candidate genes varies significantly across different ethnic populations. The mutations within these genes, in addition to common polymorphisms, are also known to contribute to sporadic disease in different populations [41-44].

\section{Hereditary Prostate Cancer 1 (HPC1)}

To accelerate progress in the field of gene discovery, the International Consortium for Prostate Cancer Genetics (ICPCG) was formed in 1995, and this group reported linkage to susceptibility locus on chromosomal region 1q24-q25 to $\mathrm{PCa}$, which they named Hereditary Prostate Cancer 1 (HPC1). HPC1, was implicated in PCa susceptibility by generating the first genome-wide linkage scan using 772 families affected by hereditary prostate cancer and this locus was found to account for about a third of highly penetrant early prostate cancer cases [45]. Importantly, the gene RNASEL is localized to HPC1 and several recent studies have linked RNASEL germline mutations to PCa susceptibility [42, 4648]. Functional studies revealed that RNASEL 1 regulates 
Table 1. Genes Influencing Prostate Cancer Risk

\begin{tabular}{|c|c|c|}
\hline Gene/(Locus) & Alterations Associated with PCa Risk & Function [Citations] \\
\hline Annexin A7 (10q21) & Reduced expression/ Loss of heterozygosity (LOH) & $\begin{array}{l}\text { Encodes for Ca- activated GTPase implicated in both exocy- } \\
\text { totic secretion in cells and control of growth [131] }\end{array}$ \\
\hline ATBF1 (16q22) & Deletion of codon 3381 (3381 del) & Gene coding for cell cycle active protein $[132,133]$ \\
\hline CDKN1B (12p11-13) p27/Kip & Reduced expression and SNP variant in codon 109 & $\begin{array}{l}\text { Inhibits cyclin-dependent kinases and blocks cell prolifera- } \\
\text { tion }[134,135]\end{array}$ \\
\hline CHEK2 (22q12.1) & Truncating mutation $1100 \mathrm{delC}$ & $\begin{array}{c}\text { Important regulator of p53 in the DNA-damage-signaling } \\
\text { pathway }[136,137]\end{array}$ \\
\hline CYP17 (10q24.3) & $\begin{array}{l}\text { Polymorphic } \mathrm{T} \text { (A1 allele) to } \mathrm{C} \text { (A2 allele) in 5' pro- } \\
\text { moter region }\end{array}$ & $\begin{array}{c}\text { Encodes enzyme P-450c17 } \alpha \text { which functions in androgen } \\
\text { biosynthesis pathway [138] }\end{array}$ \\
\hline CYP1B1 (2p21-22) & $\begin{array}{l}\text { SNP at codon } 119(\mathrm{G} \rightarrow \mathrm{T}), \text { Haplotype CGCCG of- } \\
1001 \mathrm{C} / \mathrm{T},-263 \mathrm{G} / \mathrm{A},-13 \mathrm{C} / \mathrm{T}+142 \mathrm{C} / \mathrm{G} \text { and }+355 \mathrm{G} /\end{array}$ & Involved in androgen metabolism [139] \\
\hline CYP3A4 (7q21.1) & CYP3A4 A $>$ G variant in 5' promoter & $\begin{array}{l}\text { Member of cytochrome P450 family involved in oxidation of } \\
\text { testosterone for deactivation of hormone }[140,141]\end{array}$ \\
\hline GSTP1 (11q13.3) & $313 \mathrm{~A}>\mathrm{G}$ variant & $\begin{array}{c}\text { Metabolism of carcinogens and defense against Reactive } \\
\text { Oxygen Species (ROS) [142] }\end{array}$ \\
\hline KLF6 (10p15) & $\begin{array}{c}\text { Intronic SNP - IVS1 - } 27 \mathrm{G}>\mathrm{A} \text { [IVS A allele] \& re- } \\
\text { duced expression }\end{array}$ & $\begin{array}{l}\text { Zinc finger transcription factor with a role in cell prolifera- } \\
\text { tion and differentiation }[143,144]\end{array}$ \\
\hline PTEN (10q23.3) & $\begin{array}{c}\text { Reduced expression } \\
\text { Somatic mutations/deletion } \\
\text { Hypermethylation }\end{array}$ & $\begin{array}{l}\text { Acts as tumor suppressor and codes for protein that regulates } \\
\text { cell cycle and prevents cell proliferation [145-147] }\end{array}$ \\
\hline NKX3.1 (8p21) & $\begin{array}{l}\text { Loss of heterozygosity (LOH), Reduced expression, } \\
\text { T164A }\end{array}$ & Homeodomain containing transcription factor [148-152] \\
\hline
\end{tabular}

Genetic alterations (SNPs*, deletions, LOH*, copy number aberrations) and/or altered gene expression patterns affecting prostate cancer risk in different ethnic populations. *SNP - Single Nucleotide Polymorphism *LOH- Loss of heterozygosity.

cell proliferation and apoptosis through interferon-regulated 2-5A pathway and is a candidate tumor suppressor gene [49]. In particular, Arg 462 Glu [R462Q], a common and well documented missense variant, with reduced enzymatic activity compared to wild type, has been implicated in prostate cancer risk from several epidemiologic and functional studies $[42,48]$. A large, controlled sib-pair study (family-based case-control study) implicated the R462Q variant in up to $13 \%$ of unselected prostate cancer cases [42]. One mutated copy of R462Q increased the risk of PCa by about $50 \%$. In addition, rare mutations of RNASEL are associated with different ethnic groups. A founder and deleterious frame shift mutation 471delAAAG was identified in a single Ashkenazi Jewish cohort [50]. In another study, the 471del AAAG mutation was detected in a single male with Prostate cancer $(1 / 294,0.3 \%)$, in two ovarian cancer patients $(2 / 141$, $1.4 \%)$ and in one of 242 healthy controls (0.41\%) [51]. A truncating mutation, E265X, found in Finnish hereditary PCa families, showed an association with increased risk of prostate cancer [48]. PCa patients carrying 471del AAAG and E265X mutations showed loss of heterozygosity of wild type allele in microdissected prostate tumor DNAs [46, 47]. Despite these reports supporting the involvement of RNASEL in PCa etiology [42, 46-48], others have reported no link of RNASEL to PCa [52-54]. This discrepancy may be attributable to either population differences and/or distinct study designs directly or indirectly modulating the impact of RNASEL on prostate carcinogenesis.

Further intriguing is the role of RNASEL in viral defense as an important effector of antiviral action of interferons. Urisman et al. (2006) [14] explored a possible link between incidence of viral infection and RNASEL genotypes in prostate cancer patients. Using DNA microarray-based strategy (DNA ViroChip) they identified the presence of novel gammaretroviral (XMRV) sequences in cDNA samples from seven of $11(60 \%)$ R462Q homozygous (QQ) cases, and in one of eight $(10 \%)$ heterozygous (RQ) and homozygous wild-type (RR) cases.

\section{HPC2 (ELAC2) - [tRNA Processing Endoribonuclease]}

HPC2 located on chromosomal region $17 \mathrm{p} 11$, harbors ELAC2, which is the first candidate gene identified for human prostate cancer based on linkage analysis and positional cloning [55]. ELAC2 encodes a 3 'processing endoribonuclease, associated with gamma tubulin, which is a component of mitotic apparatus suggesting a possible role of ELAC2 in cell cycle control [56]. A number of germline variants including mutations have been identified in this gene. Specifically, two common missense alterations Ser217Leu (S217L) and Ala541Thr (A541T), are associated with increased risk of PCa in men belonging to hereditary prostate cancer families $[43,44,55,57]$. A number of polymorphic variants have also been described linked to PCa risk in various populations [44, 58-63].

\section{MSR1 [Macrophage Scavenger Receptor 1]}

The chromosomal 8p22 region is one of the loci that are frequently deleted in PCa and also linked to hereditary prostate cancer [64-66]. MSR1 is a candidate PCa susceptibility gene that was identified by a combination of family-based linkage and association studies and systematic evaluations of genes at 8 p22-23 region by screening for mutations in 
probands of 190 hereditary prostate cancer families [65]. The MSR gene encodes proteins that function with responses to infections, which may play a role in susceptibility to prostate cancer [16]. It can also bind to bacteria and modified lipoproteins [67] and functions in several processes relevant to prostate carcinogenesis [68]. Mutations in MSR1, including truncating mutations have been shown to be associated with $\mathrm{PCa}$ risk both in hereditary and sporadic cancers. Xu et al. $[65,66]$ carried out a comprehensive genetic study using a large number of subjects from multiple populations (men from hereditary prostate cancer families, non- hereditary prostate cancer men, and case-control studies conducted using African-American men) and screened for germline variants in MSR1 among probands in each group. Six rare missense mutations [Pro36Ala, Ser41Tyr, Val113Ala, Asp174 Tyr, Pro275Ala, Gly369Ser] and one nonsense [Arg 293X] mutation within MSR1 were observed to co-segregate with the disease in hereditary prostate cancer (HPC) families, $(p=0.0007)$ [65]. Furthermore, the prevalence of MSR1 mutations in European and African American probands was substantially higher compared to unaffected men [65]. Arg 293X and Ser 41 Tyr were the most common mutations detected among PCa patients of European and AfricanAmerican descent, respectively [66]. Seppala et al. [69] screened the youngest affected member from each of 120 hereditary prostate cancer families for MSR1 mutations by Single-strand conformational polymorphism analysis. Three MSR1 variants (R293X, P275A, -1473A>G) were identified and they reported no significantly elevated or lowered risks for PCa for the carriers of these variants. However, the mean age of diagnosis of R293X mutation carriers among the herediatary prostate cancer probands was significantly lower compared with noncarriers (55.4 versus 65.4 years; t test, $\mathrm{p}=0.04)$.

\section{EphB2 [Eph Receptor B2]}

The EphB2 gene encodes for a receptor tyrosine kinase. It was recently identified as a tumor-suppressor gene in DU145 PCa cell line and in primary prostate tumor specimens using a combination of strategy of nonsense -mediated mRNA decay microarray profiling and array-based CGH [70]. EphB2 maps to chromosomal region 1 p36 previously shown to be linked to hereditary prostate cancer among ethnically diverse sets of families [71-73]. Somatic mutations in EphB2 occur in $\sim 10 \%$ of sporadic prostate tumors. Kittles et al. recently (2006) [74] evaluated the contribution of EphB2 to inherited PCa susceptibility in African Americans (AA) by screening for germline polymorphisms. Ten coding sequence variants were identified, including the K1019X (3055A to T), a germline nonsense mutation, which was present in $15.3 \%$ of the African-American hereditary prostate cancer probands, but only 1.7\% European American control samples. This mutation increased the risk for PCa over twofold $[p=0.003]$. Although the functional significance of $\mathrm{K} 1019 \mathrm{X}$ mutation is unknown, it suggests a pathogenic role for $\mathrm{EphB} 2$ in $\mathrm{PCa}$, which warrants further investigation.

\section{BRCA1/BRCA2}

Germline mutations of tumor suppressor genes BRCA1 (17q21) and BRCA2 (13q12) are linked to hereditary breast cancers. While multiple studies have excluded a potential role for BRCA1 in prostate cancer, an association with pros- tate cancer is reported in breast-ovarian cancer families with BRCA2 mutations accounting for about 2-5\% of early-onset prostate cancers [75-77]. A common founder mutation (6174delT) has been identified in Ashkenazi Jewish population and this allele showed a significant association with prostate cancer risk [78].

\section{Androgen Receptor (AR)}

Androgens, which exert their effect via Androgen Receptor (AR), are essential for the prostate development and maintenance [[79]. The AR gene located on the X chromosome contains polymorphic trinucleotide repeats (CAG or GGC) in exon 1 and these encode for a variable length of glutamine and glycine tract, respectively, in the AR protein. There is an inverse relationship between repeat length and AR transcriptional activity [80]. Reduced repeat length is associated with prostate cancer recurrence and early-onset disease $[39,81]$. The number of CAG repeats ranges from 831 [82]. Decreased transactivation activity and binding affinity for androgens is associated with increased number of repeats and it may confer a protective effect in terms of prostate cancer risk. Whereas somatic alteration of the repeat length is very rare, a shorter CAG repeat has been shown to be associated with increased risk and more aggressive tumor features (high tumor stage and grade, metastasis, mortality)[83] The GGC repeat also appears to be associated with prostate cancer risk [84].

The association between AR and PCa has been well established and AR expression is sustained even at the most advanced phases of androgen-independent disease [85]. Therefore, androgen- ablation and antiandrogen therapy form important treatment regimen of the disease, though most patients go on to develop and will die of androgenindependent prostate cancer. There is a plethora of literature available explaining the possible mechanisms of $\mathrm{AR}$ and AR-regulated gene expression in recurrent disease. Some of the mechanisms include: 1 . AR plays a role as a potent oncogene; 2. AR activity is enhanced by genomic amplification in approximately one-third of tumors even in the relative absence of androgen [25] 3. In some prostate carcinomas, somatic AR mutations alter the specificity of the AR receptor, enhancing its hormone sensitivity [21, 25, 86, 87]. Germline polymorphisms in the trinucleotide repeat of the AR gene, which probably affect AR activities, have been linked to increased prostate cancer risk. Others have reported that activation of AR in androgen-independent disease may also be accomplished by induction of co-activators such as $\beta$-catenin and p160 family members [88-90]. $\beta$-catenin is rarely mutated in $\mathrm{PCa}$, but can activate AR cause its colocalization to the nucleus and enhance hormone sensitivity $[89,90]$.

\section{8q24 REGION AND PROSTATE CANCER RISK}

To date multiple chromosomal aberrations [91] as well as certain chromosomal regions $(1 \mathrm{q}, 17 \mathrm{p}, 8 \mathrm{p}$ ) have been identified as likely harboring PCa susceptibility genes [40]. Mutations and sequence variants in many candidate genes from these regions have been reported to be associated with $\mathrm{PCa}$ risk $[46,55,65,68]$. Emerging evidence indicates linkage of both $8 \mathrm{p}$ and $8 \mathrm{q}$ regions to $\mathrm{PCa}$ and frequent genomic rearrangements are observed at $8 p[53,72,92-95]$ as well as $8 \mathrm{q}$ $[96,97]$ regions in prostate tumors. 
It has been known for some time that amplification, or gain of chromosomal region 8q24 (including the c-MYC region) is a frequent event in PCa [98]. Genome-wide association $[99,100]$ studies and studies involving Single Nucleotide Polymorphism(SNP) genotyping have identified several SNPs associated with PCa risk [101, 102]. Recently, Amundadottir et al. (2006) [103] localized a region at 8q24 locus via linkage analysis and identified specific variants in a region spanning from $128.54-128.62 \mathrm{Mb}$ that were associated with increased risk of prostate cancer in Icelandic families. Further analysis of this region led to the identification of several common nucleotide variants associated with $\mathrm{PCa}$ in European and African populations. Two representative markers, a microsatellite repeat DG8S737 and a SNP rs1447295 showed the strongest association with $\mathrm{PCa}$ in three case-control series of European ancestry (Iceland \& Sweden), as well as a cohort of US Caucasians [99, 103]. In an independent report, Freedman et al. (2006) [104] confirmed the association between rs 1447295 and PCa risk (overall $\mathrm{p}<4.2 \times 10^{-9}$ ) by using four case-control study populations including Japanese Americans, Native Hawaiians, Latino Americans, and European Americans. Among African Americans, the association was statistically significant in men diagnosed with $\mathrm{PCa}$ at an early age $[<55$ years of age] $(\mathrm{p}=0.011)$ and insignificant for those diagnosed at a later age $(p=0.924)$. More recently, studies by Gudmundsson et al. (2007) [101], Haiman et al. (2007) [105], and Yeager et al. (2007) [102] provided further evidence by demonstrating an extraordinarily strong association (adjusted $\mathrm{p}$ value $=$ $4 \times 10^{-29}$ ) of rs1447295 SNP with PCa. Linkage scans and Genome- wide association studies have identified this genomic region also associated with risks of other cancers including CRC and breast [106, 107]. The 8q24 region appears to be a "gene-poor" region and is a common location for somatic gains for PCa. These findings are intriguing and suggest that the vast proportion of the non-coding repetitive regions of the genome may contain novel regulatory elements or even genes that we have yet to identify and understand. Finally, mechanism by which the nucleotide marker and the SNP contribute to an increased risk of prostate remains to be elucidated.

\section{GENE FUSIONS AS NEW GENETIC MARKERS FOR PROSTATE CANCER}

Gene rearrangements are associated with a number of cancers especially lymphomas, leukemias, and sarcomas. Recent studies have uncovered specific gene rearrangements implicated in a subset of prostate cancers. These novel rearrangements were discovered using "Oncomine", a collective database of gene expression profiling generated from various cancer studies across the globe [108]. One such rearrangement, identified using FISH and RTPCR, involves ETS tran-

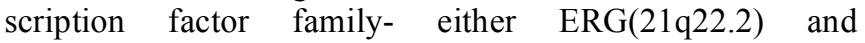
ETV1(7p21.2) or ETV4 (17q21) with TMPRSS2 (21q22.3) [109-113]. ERG and ETV1/4 are ETS transcription factor genes and TMPRSS2 is an androgen-regulated gene. While TMPRSS2: ERG fusions are the most predominant subtype of ETS gene fusions ( $50 \%$ of PCa), those involving ETV1 or ETV4 occur in $\sim 1-10 \%$ of PCa cases $[111,114-118]$. Although the fusion event seems to be cancer-specific (40-80\% of cancers) and rare in BPH, it is detected in about $20 \%$ of preneoplasic (PIN) lesions $[113,116]$. These rearrangements occur via different processes involving either a deletion (due to loss of 3' TMPRSS2 signal) or a translocation (split of 5' and 3' TMPRSS2 signals), or alternatively involving both mechanisms in different tumor foci [119].

The TMPRSS2-ERG fusion is considered to be an early event in PCa development. The fusions were detected noninvasively in urine sample of patients with clinically localized PCa [120]. The test was developed using RNA amplification and quantitative PCR [120]. When urine was collected from 19 patients with clinically localized prostate cancer, $42 \%$ of the patients had the gene fusion detected, consistent with that found in tissue data analysis. The translocation of ERG and ETV1 may be redundant because only one or the other was found fused to the TMPRSS2 regulatory region in any given tumor.

Mosquera et al. (2007) [121] demonstrated a significant link between chromosomal fusion status in the prostate tumors and the tumor phenotype. They studied 253 prostate cancers for the presence of characteristic histopathological features using an ERG break-apart FISH assay. Five out of eight morphological features were significantly associated with the presence of TMPRSS2-ERG fusions in cancers ( $p$ $<0.05)$. These were as follows: blue-tinged mucin, cribiform growth pattern, macronucleoli, intraductal tumor spread, and signet cell features. Only $24 \%$ of tumors without any of these features displayed the TMPRSS2-ERG fusion. Mucin positive carcinomas more often harbor such gene fusions compared to mucin-negative tumors $(p=0.004)$ [119]. It is likely that TMPRSS2-ERG over expression may initiate specific molecular pathways that favor a typical phenotype for the tumors. The fusion-specific phenotype may have prognostic implications, and merits further investigation using large series of prostate cancers with known fusion status. Emerging data suggest that gene fusion carrying prostate tumors exhibit a distinct clinical course and thus support it's use as a potential prognostic biomarker.

More recently, Helgeson et al. 2008 [109] identified additional 5' partners in ETV1 fusions including TMPRSS2, SLC45A3, HERV-K_22q11.23, C150RF21, and HNRPA 2B1. These 5' partners are differentially regulated by androgen (androgen-induced, androgen-repressed and androgen insensitive) and they define distinct classes of ETS gene rearrangements. To date, the partners have only been identified in ETV1 fusions, it is not known if they fuse with ERG or additional ETS family members.

\section{DNA METHYLATION AND PROSTATE CANCER}

Hypermethylation of cytosine guanine dinucleotide islands (CGI) at promoter regions of tumor suppressor genes has been recognized for a number of tumors as an important event in tumorigenesis, including prostate cancer. $\mathrm{CpG}$ island hypermethylation causes gene silencing through transcriptional inactivation and thereby contributes to prostate cancer development and progression. Hypermethylation of candidate genes has been studied contribution of panel of some genes has been evaluated for potential role as biomarkers for diagnosis and/or prognosis of prostate cancer [26, 122-126]. GSTP1 is the most consistently hypermethylated marker in prostate cancer $[127,128]$. GSTP1 hypermethylation was found to be highly tumor-specific, but also prevalent in HGPIN lesions, which makes it an attractive early 
detection marker [127]. GSTP1 hypermethylation has been also studied in urine sediment as a non-interventional test for determining the need for prostate biopsies and as a biomarker for diagnosis $[15,129]$. Emerging evidence suggests that a defined panel of methylated genes rather than a single gene is more likely responsible for prostate cancer progression. Candidate genes most commonly studied for methylation include APC, DAPK, ECDH1, GSTP1, MGMT, P14 [ARF], P16, RAR 32 , RASSF1a, and TIMP3 [28, 130]. Hoque et al. (2005) [130] compared urine sediment from 52 prostate cancer patients undergoing radical prostatectomy with that of 91 age-matched controls. All 52 cancer patients had at least one hypermethylated gene, and $80 \%$ had 3 or more hypermethylated genes. The 4 most commonly methylated genes were GSTP1, p16, ARF, and MGMT. None of the controls showed hypermethylation of any gene. Recently, Roupret et al. (2007) [28] analyzed methylation patterns in 95 patients undergoing radical prostactomy and 38 agematched controls with negative prostate biopsies. Eight of the loci had increased methylation in cancer patients compared to the controls $(\mathrm{p}<0.05)$. Again, the methylated panel of genes consisted of GSTP1, APC, RASSF1a, and RAR $\beta 2$. The sensitivity for prostate cancer detection was $86 \%$ and diagnostic accuracy was reported to be $89 \%$. The potential for DNA methylation in the clinical arena including it's role as biomarker for early cancer detection, as prognostic indicator for $\mathrm{PCa}$, as well as it's potential in designing novel therapeutic strategies for PCa has been reviewed [26].

\section{CONCLUSION}

The genetic basis of $\mathrm{PCa}$ is complex and includes both heritable and somatic genetic alterations. Traditional linkage studies and population-based genome-wide association studies have identified many candidate susceptibility loci, however the results from these studies have not been consistently replicated, possibly due to phenocopies in families and/or due to locus heterogeneity. Recent advances have provided significant insights into initiation and progression of prostate cancer, however much work is needed to elucidate how these alterations relate to each other. Future studies need to focus on these issues by building multifactorial inheritance models that account for interplay between genetic, epigenetic and environmental factors in prostate carcinogenesis.

\section{ACKNOWLEDGEMENTS}

We are grateful to Miralem Mrkonjic and Ken Kron for their useful comments and suggestions during the preparation of this article.

We would like to acknowledge the support from Canadian Prostate Cancer Research Initiative (CPCRI) and National Cancer Institute of Canada.

\section{REFERENCES}

[1] Ruijter E, Montironi R, van de Kaa C, Schalken J. Molecular changes associated with prostate cancer development. Anal Quant Cytol Histol 2001; 23(1): 67-88.

[2] Jemal A, Murray T, Ward E, et al. Cancer statistics, 2005. CA Cancer J Clin 2005; 55(1): 10-30.

[3] Parkin DM, Bray F, Ferlay J, Pisani P. Global cancer statistics, 2002. CA Cancer J Clin 2005; 55(2): 74-108.

[4] Ghafoor A, Jemal A, Cokkinides V, et al. Cancer statistics for African Americans. CA Cancer J Clin 2002; 52(6): 326-41.

[5] Jemal A, Tiwari RC, Murray T, et al. Cancer statistics, 2004. CA Cancer J Clin 2004; 54(1): 8-29.
[6] Sakr WA, Grignon DJ, Crissman JD, et al. High grade prostatic intraepithelial neoplasia (HGPIN) and prostatic adenocarcinoma between the ages of 20-69: an autopsy study of 249 cases. In Vivo 1994; 8(3): 439-43.

[7] Pienta KJ, Esper PS. Risk factors for prostate cancer. Ann Intern Med 1993; 118(10): 793-803.

[8] Gann PH. Risk factors for prostate cancer. Rev Urol 2002; 4 Suppl 5: S3-10.

[9] Giovannucci E, Liu Y, Platz EA, Stampfer MJ, Willett WC. Risk factors for prostate cancer incidence and progression in the health professionals follow-up study. Int J Cancer 2007; 121(7): 1571-8.

[10] Giovannucci E, Rimm EB, Colditz GA, et al. A prospective study of dietary fat and risk of prostate cancer. J Natl Cancer Inst 1993; 85(19): 1571-9.

[11] Santillo VM, Lowe FC. Role of vitamins, minerals and supplements in the prevention and management of prostate cancer. Int Braz J Urol 2006; 32(1): 3-14.

[12] Fleshner N, Zlotta AR. Prostate cancer prevention: past, present, and future. Cancer 2007; 110(9): 1889-99.

[13] Cheung E, Wadhera P, Dorff T, Pinski J. Diet and prostate cancer risk reduction. Expert Rev Anticancer Ther 2008; 8(1): 43-50.

[14] Urisman A, Molinaro RJ, Fischer N, et al. Identification of a novel Gammaretrovirus in prostate tumors of patients homozygous for R462Q RNASEL variant. PLoS Pathog 2006; 2(3): e25.

[15] Gonzalgo ML, Isaacs WB. Molecular pathways to prostate cancer. J Urol 2003; 170(6 Pt 1): 2444-52.

[16] Nelson WG, De Marzo AM, Isaacs WB. Prostate cancer. N Engl J Med 2003; 349(4): 366-81.

[17] Montironi R, Scarpelli M, Lopez Beltran A. Carcinoma of the prostate: inherited susceptibility, somatic gene defects and androgen receptors. Virchows Arch 2004; 444(6): 503-8.

[18] Crawford ED. Epidemiology of prostate cancer. Urology 2003; 62(6 Suppl 1): 3-12.

[19] Dong JT. Prevalent mutations in prostate cancer. J Cell Biochem 2006; 97(3): 433-47.

[20] Shand RL, Gelmann EP. Molecular biology of prostate-cancer pathogenesis. Curr Opin Urol 2006; 16(3): 123-31.

[21] Yong EL, Lim J, Qi W, Ong V, Mifsud A. Molecular basis of androgen receptor diseases. Ann Med 2000; 32(1): 15-22.

[22] McCall P, Gemmell LK, Mukherjee R, Bartlett JM, Edwards J. Phosphorylation of the androgen receptor is associated with reduced survival in hormone-refractory prostate cancer patients. Br J Cancer 2008; 98(6): 1094-101.

[23] Silva Neto B, Koff WJ, Biolchi V, et al. Polymorphic CAG and GGC repeat lengths in the androgen receptor gene and prostate cancer risk: analysis of a Brazilian population. Cancer Invest 2008; 26(1): 74-80.

[24] Linja MJ, Visakorpi T. Alterations of androgen receptor in prostate cancer. J Steroid Biochem Mol Biol 2004; 92(4): 255-64.

[25] Ford OH 3rd, Gregory CW, Kim D, Smitherman AB, Mohler JL. Androgen receptor gene amplification and protein expression in recurrent prostate cancer. J Urol 2003; 170(5): 1817-21.

[26] Perry AS, Foley R, Woodson K, Lawler M. The emerging roles of DNA methylation in the clinical management of prostate cancer. Endocr Relat Cancer 2006; 13(2): 357-77.

[27] Ellinger J, Bastian PJ, Jurgan T, et al. $\mathrm{CpG}$ island hypermethylation at multiple gene sites in diagnosis and prognosis of prostate cancer. Urology 2008; 71(1): 161-7.

[28] Roupret M, Hupertan V, Yates DR, et al. Molecular detection of localized prostate cancer using quantitative methylation-specific PCR on urinary cells obtained following prostate massage. Clin Cancer Res 2007; 13(6): 1720-5.

[29] Ghadirian P, Howe GR, Hislop TG, Maisonneuve P. Family history of prostate cancer: a multi-center case-control study in Canada. Int J Cancer 1997; 70(6): 679-81.

[30] Carter BS, Beaty TH, Steinberg GD, Childs B, Walsh PC. Mendelian inheritance of familial prostate cancer. Proc Natl Acad Sci USA 1992; 89(8): 3367-71.

[31] Steinberg GD, Epstein JI, Piantadosi S, Walsh PC. Management of stage D1 adenocarcinoma of the prostate: the Johns Hopkins experience 1974 to 1987. J Urol 1990; 144(6): 1425-32.

[32] Whittemore AS, Wu AH, Kolonel LN, et al. Family history and prostate cancer risk in black, white, and Asian men in the United States and Canada. Am J Epidemiol 1995; 141(8): 732-40.

[33] Schaid DJ. The complex genetic epidemiology of prostate cancer. Hum Mol Genet 2004; 13 Spec No 1: R103-21. 
[34] Filion E, Taussky D, Bahary JP, Maugard CM. Higher frequency of familial clustering of prostate cancer in French-Canadian men. J Urol 2007; 178(4 Pt 1): 1265-9 discussion 70.

[35] Carter BS, Carter HB, Isaacs JT. Epidemiologic evidence regarding predisposing factors to prostate cancer. Prostate 1990; 16(3): 18797.

[36] Hemminki K, Sundquist J, Bermejo JL. How common is familial cancer? Ann Oncol 2008; 19(1): 163-7.

[37] Carter BS, Bova GS, Beaty TH, et al. Hereditary prostate cancer: epidemiologic and clinical features. J Urol 1993; 150(3): 797-802.

[38] Bova GS, Partin AW, Isaacs SD, et al. Biological aggressiveness of hereditary prostate cancer: long-term evaluation following radical prostatectomy. J Urol 1998; 160 (3 Pt 1): 660-3

[39] Bratt O. Hereditary prostate cancer: clinical aspects. J Urol 2002; 168(3): 906-13

[40] Xu J, Dimitrov L, Chang BL, et al. A combined genomewide linkage scan of 1,233 families for prostate cancer-susceptibility genes conducted by the international consortium for prostate cancer genetics. Am J Hum Genet 2005; 77(2): 219-29.

[41] Miller DC, Zheng SL, Dunn RL, et al. Germ-line mutations of the macrophage scavenger receptor 1 gene: association with prostate cancer risk in African-American men. Cancer Res 2003; 63(13): 3486-9.

[42] Casey G, Neville PJ, Plummer SJ, et al. RNASEL Arg462Gln variant is implicated in up to $13 \%$ of prostate cancer cases. Nat Genet 2002; 32(4): 581-3.

[43] Rebbeck TR, Walker AH, Zeigler-Johnson C, et al. Association of HPC2/ELAC2 genotypes and prostate cancer. Am J Hum Genet 2000; 67(4): 1014-9.

[44] Stanford JL, Sabacan LP, Noonan EA, et al. Association of HPC2/ELAC2 polymorphisms with risk of prostate cancer in a population-based study. Cancer Epidemiol Biomarkers Prev 2003; 12(9): 876-81.

[45] Xu J. Combined analysis of hereditary prostate cancer linkage to 1q24-25: results from 772 hereditary prostate cancer families from the International Consortium for Prostate Cancer Genetics. Am J Hum Genet 2000; 66(3): 945-57.

[46] Carpten J, Nupponen N, Isaacs S, et al. Germline mutations in the ribonuclease L gene in families showing linkage with HPC1. Nat Genet 2002; 30(2): 181-4

[47] Rennert H, Bercovich D, Hubert A, et al. A novel founder mutation in the RNASEL gene, 471delAAAG, is associated with prostate cancer in Ashkenazi Jews. Am J Hum Genet 2002; 71(4): 981-4.

[48] Rokman A, Ikonen T, Seppala EH, et al. Germline alterations of the RNASEL gene, a candidate HPC1 gene at 1q25, in patients and families with prostate cancer. Am J Hum Genet 2002; 70(5): 1299304

[49] Lengyel P. Tumor-suppressor genes: news about the interferon connection. Proc Natl Acad Sci USA 1993; 90(13): 5893-5.

[50] Kotar K, Hamel N, Thiffault I, Foulkes WD. The RNASEL 471delAAAG allele and prostate cancer in Ashkenazi Jewish men. J Med Genet 2003; 40(3): e22.

[51] Dagan E, Laitman Y, Levanon N, et al. The 471delAAAG mutation and C353T polymorphism in the RNASEL gene in sporadic and inherited cancer in Israel. Fam Cancer 2006; 5(4): 389-95.

[52] Downing SR, Hennessy KT, Abe M, Manola J, George DJ, Kantoff $\mathrm{PW}$. Mutations in ribonuclease $\mathrm{L}$ gene do not occur at a greater frequency in patients with familial prostate cancer compared with patients with sporadic prostate cancer. Clin Prostate Cancer 2003; 2(3): 177-80.

[53] Wiklund F, Jonsson BA, Goransson I, Bergh A, Gronberg H. Linkage analysis of prostate cancer susceptibility: confirmation of linkage at 8 p22-23. Hum Genet 2003; 112(4): 414-8.

[54] Maier C, Haeusler J, Herkommer K, et al. Mutation screening and association study of RNASEL as a prostate cancer susceptibility gene. Br J Cancer 2005; 92(6): 1159-64.

[55] Tavtigian SV, Simard J, Teng DH, et al. A candidate prostate cancer susceptibility gene at chromosome 17p. Nat Genet 2001;27(2): $172-80$.

[56] Korver W, Guevara C, Chen Y, et al. The product of the candidate prostate cancer susceptibility gene ELAC2 interacts with the gamma-tubulin complex. Int J Cancer 2003; 104(3): 283-8.

[57] Takahashi $\mathrm{H}, \mathrm{Lu} \mathrm{W}$, Watanabe M, et al. Ser217Leu polymorphism of the HPC2/ELAC2 gene associated with prostatic cancer risk in Japanese men. Int J Cancer 2003; 107(2): 224-8.
[58] Camp NJ, Tavtigian SV. Meta-analysis of associations of the Ser217Leu and Ala541Thr variants in ELAC2 (HPC2) and prostate cancer. Am J Hum Genet 2002; 71(6): 1475-8.

[59] Fujiwara H, Emi M, Nagai $\mathrm{H}$, et al. Association of common missense changes in ELAC2 (HPC2) with prostate cancer in a Japanese case-control series. J Hum Genet 2002; 47(12): 641-8.

[60] Suarez BK, Gerhard DS, Lin J, et al. Polymorphisms in the prostate cancer susceptibility gene HPC2/ELAC2 in multiplex families and healthy controls. Cancer Res 2001; 61(13): 4982-4.

[61] Meitz JC, Edwards SM, Easton DF, et al. HPC2/ELAC2 polymorphisms and prostate cancer risk: analysis by age of onset of disease. Br J Cancer 2002; 87(8): 905-8.

[62] Adler D, Kanji N, Trpkov K, Fick G, Hughes RM. HPC2/ELAC2 gene variants associated with incident prostate cancer. J Hum Genet 2003; 48(12): 634-8.

[63] Yokomizo A, Koga H, Kinukawa N, et al. HPC2/ELAC2 polymorphism associated with Japanese sporadic prostate cancer. Prostate 2004; 61(3): 248-52.

[64] Lieberfarb ME, Lin M, Lechpammer M, et al. Genome-wide loss of heterozygosity analysis from laser capture microdissected prostate cancer using single nucleotide polymorphic allele (SNP) arrays and a novel bioinformatics platform dChipSNP. Cancer Res 2003; 63(16): 4781-5.

[65] Xu J, Zheng SL, Komiya A, et al. Germline mutations and sequence variants of the macrophage scavenger receptor 1 gene are associated with prostate cancer risk. Nat Genet 2002; 32(2): 321-5.

[66] Xu J, Zheng SL, Komiya A, et al. Common sequence variants of the macrophage scavenger receptor 1 gene are associated with prostate cancer risk. Am J Hum Genet 2003; 72(1): 208-12.

[67] Platt N, Gordon S. Is the class A macrophage scavenger receptor (SR-A) multifunctional? - The mouse's tale. J Clin Invest 2001; 108(5): 649-54.

[68] Lissbrant IF, Stattin P, Wikstrom P, Damber JE, Egevad L, Bergh A. Tumor associated macrophages in human prostate cancer: relation to clinicopathological variables and survival. Int J Oncol 2000; 17(3): 445-51.

[69] Seppala EH, Ikonen T, Autio V, et al. Germ-line alterations in MSR1 gene and prostate cancer risk. Clin Cancer Res 2003; 9(14) 5252-6.

[70] Huusko P, Ponciano-Jackson D, Wolf M, et al. Nonsense-mediated decay microarray analysis identifies mutations of EPHB2 in human prostate cancer. Nat Genet 2004; 36(9): 979-83.

[71] Gibbs M, Chakrabarti L, Stanford JL, et al. Analysis of chromosome 1q42.2-43 in 152 families with high risk of prostate cancer. Am J Hum Genet 1999; 64(4): 1087-95.

[72] Matsui H, Suzuki K, Ohtake N, et al. Genomewide linkage analysis of familial prostate cancer in the Japanese population. J Hum Genet 2004; 49(1): 9-15.

[73] Brown WM, Lange EM, Chen H, et al. Hereditary prostate cancer in African American families: linkage analysis using markers that map to five candidate susceptibility loci. Br J Cancer 2004; 90(2): 510-4.

[74] Kittles RA, Baffoe-Bonnie AB, Moses TY, et al. A common nonsense mutation in EphB2 is associated with prostate cancer risk in African American men with a positive family history. J Med Genet 2006; 43(6): 507-11

[75] Edwards SM, Kote-Jarai Z, Meitz J, et al. Two percent of men with early-onset prostate cancer harbor germline mutations in the BRCA2 gene. Am J Hum Genet 2003; 72(1): 1-12.

[76] Simard J, Dumont M, Labuda D, et al. Prostate cancer susceptibility genes: lessons learned and challenges posed. Endocr Relat Cancer 2003; 10(2): 225-59.

[77] Bratt O, Kristoffersson U, Lundgren R, Olsson H. Familial and hereditary prostate cancer in southern Sweden. A population-based case-control study. Eur J Cancer 1999; 35(2): 272-7.

[78] Kirchhoff T, Kauff ND, Mitra N, et al. BRCA mutations and risk of prostate cancer in Ashkenazi Jews. Clin Cancer Res 2004; 10(9): 2918-21.

[79] Kokontis JM, Liao S. Molecular action of androgen in the normal and neoplastic prostate. Vitam Horm 1999; 55: 219-307.

[80] Chamberlain NL, Driver ED, Miesfeld RL. The length and location of CAG trinucleotide repeats in the androgen receptor N-terminal domain affect transactivation function. Nucleic Acids Res 1994; 22(15): 3181-6. 
[81] Nam RK, Elhaji Y, Krahn MD, et al. Significance of the CAG repeat polymorphism of the androgen receptor gene in prostate cancer progression. J Urol 2000; 164(2): 567-72.

[82] Ekman P. Genetic and environmental factors in prostate cancer genesis: identifying high-risk cohorts. Eur Urol 1999; 35(5-6): 3629 .

[83] Giovannucci E, Stampfer MJ, Krithivas K, et al. The CAG repeat within the androgen receptor gene and its relationship to prostate cancer. Proc Natl Acad Sci USA 1997; 94(7): 3320-3.

[84] Chang BL, Zheng SL, Hawkins GA, et al. Polymorphic GGC repeats in the androgen receptor gene are associated with hereditary and sporadic prostate cancer risk. Hum Genet 2002; 110(2): 122-9.

[85] Heinlein CA, Chang C. Androgen receptor in prostate cancer. Endocr Rev 2004; 25(2): 276-308.

[86] Newmark JR, Hardy DO, Tonb DC, et al. Androgen receptor gene mutations in human prostate cancer. Proc Natl Acad Sci USA 1992; 89(14): 6319-23.

[87] Taplin ME, Rajeshkumar B, Halabi S, et al. Androgen receptor mutations in androgen-independent prostate cancer: Cancer and Leukemia Group B Study 9663. J Clin Oncol 2003; 21(14): 2673-8.

[88] Slagsvold T, Kraus I, Fronsdal K, Saatcioglu F. DNA bindingindependent transcriptional activation by the androgen receptor through triggering of coactivators. J Biol Chem 2001; 276(33): 31030-6.

[89] Song LN, Herrell R, Byers S, Shah S, Wilson EM, Gelmann EP. Beta-catenin binds to the activation function 2 region of the androgen receptor and modulates the effects of the N-terminal domain and TIF2 on ligand-dependent transcription. Mol Cell Biol 2003; 23(5): 1674-87.

[90] Yang F, Li X, Sharma M, et al. Linking beta-catenin to androgensignaling pathway. J Biol Chem 2002; 277(13): 11336-44.

[91] Saramaki O, Visakorpi T. Chromosomal aberrations in prostate cancer. Front Biosci 2007; 12: 3287-301.

[92] Xu J, Zheng SL, Hawkins GA, et al. Linkage and association studies of prostate cancer susceptibility: evidence for linkage at 8p2223. Am J Hum Genet 2001; 69(2): 341-50.

[93] Goddard KA, Witte JS, Suarez BK, Catalona WJ, Olson JM. Model-free linkage analysis with covariates confirms linkage of prostate cancer to chromosomes 1 and 4. Am J Hum Genet 2001; 68(5): 1197-206.

[94] Janer M, Friedrichsen DM, Stanford JL, et al. Genomic scan of 254 hereditary prostate cancer families. Prostate 2003; 57(4): 309-19.

[95] Maier C, Herkommer K, Hoegel J, Vogel W, Paiss T. A genomewide linkage analysis for prostate cancer susceptibility genes in families from Germany. Eur J Hum Genet 2005; 13(3): 352-60.

[96] Visakorpi T, Kallioniemi AH, Syvanen AC, et al. Genetic changes in primary and recurrent prostate cancer by comparative genomic hybridization. Cancer Res 1995; 55(2): 342-7.

[97] Cher ML, Bova GS, Moore DH, et al. Genetic alterations in untreated metastases and androgen-independent prostate cancer detected by comparative genomic hybridization and allelotyping. Cancer Res 1996; 56(13): 3091-102.

[98] Sato K, Qian J, Slezak JM, et al. Clinical significance of alterations of chromosome 8 in high-grade, advanced, nonmetastatic prostate carcinoma. J Natl Cancer Inst 1999; 91(18): 1574-80.

[99] Wang L, McDonnell SK, Slusser JP, et al. Two common chromosome $8 \mathrm{q} 24$ variants are associated with increased risk for prostate cancer. Cancer Res 2007; 67(7): 2944-50.

[100] Suuriniemi M, Agalliu I, Schaid DJ, et al. Confirmation of a positive association between prostate cancer risk and a locus at chromosome 8q24. Cancer Epidemiol Biomarkers Prev 2007; 16(4): $809-14$.

[101] Gudmundsson J, Sulem P, Manolescu A, et al. Genome-wide association study identifies a second prostate cancer susceptibility variant at 8q24. Nat Genet 2007; 39(5): 631-7.

[102] Yeager M, Orr N, Hayes RB, et al. Genome-wide association study of prostate cancer identifies a second risk locus at $8 \mathrm{q} 24$. Nat Genet 2007; 39(5): 645-9.

[103] Amundadottir LT, Sulem P, Gudmundsson J, et al. A common variant associated with prostate cancer in European and African populations. Nat Genet 2006; 38(6): 652-8.

[104] Freedman ML, Haiman CA, Patterson N, et al. Admixture mapping identifies 8q24 as a prostate cancer risk locus in African-American men. Proc Natl Acad Sci USA 2006; 103(38): 14068-73.
[105] Haiman CA, Patterson N, Freedman ML, et al. Multiple regions within $8 \mathrm{q} 24$ independently affect risk for prostate cancer. Nat Genet 2007; 39(5): 638-44.

[106] Zanke BW, Greenwood CM, Rangrej J, et al. Genome-wide association scan identifies a colorectal cancer susceptibility locus on chromosome 8q24. Nat Genet 2007; 39(8): 989-94.

[107] Schumacher FR, Feigelson HS, Cox DG, et al. A common 8q24 variant in prostate and breast cancer from a large nested casecontrol study. Cancer Res 2007; 67(7): 2951-6.

[108] Hampton T. Tool helps cancer scientists mine genes. JAMA 2004; 292(17): 2073.

[109] Helgeson BE, Tomlins SA, Shah N, et al. Characterization of TMPRSS2: ETV5 and SLC45A3: ETV5 gene fusions in prostate cancer. Cancer Res 2008; 68(1): 73-80.

[110] Mertz KD, Setlur SR, Dhanasekaran SM, et al. Molecular characterization of TMPRSS2-ERG gene fusion in the NCI-H660 prostate cancer cell line: a new perspective for an old model. Neoplasia 2007; 9(3): 200-6.

[111] Tomlins SA, Rhodes DR, Perner S, et al. Recurrent fusion of TMPRSS2 and ETS transcription factor genes in prostate cancer. Science 2005; 310(5748): 644-8

[112] Macaluso M, Giordano A. TMPRSS2: ERG gene fusion a new genetic marker for prostate cancer progression. Cancer Biol Ther 2007; 6(1): 46-7.

[113] Mehra R, Tomlins SA, Shen R, et al. Comprehensive assessment of TMPRSS2 and ETS family gene aberrations in clinically localized prostate cancer. Mod Pathol 2007; 20(5): 538-44.

[114] Lapointe J, Kim YH, Miller MA, et al. A variant TMPRSS2 isoform and ERG fusion product in prostate cancer with implications for molecular diagnosis. Mod Pathol 2007; 20(4): 467-73.

[115] Tomlins SA, Laxman B, Dhanasekaran SM, et al. Distinct classes of chromosomal rearrangements create oncogenic ETS gene fusions in prostate cancer. Nature 2007; 448(7153): 595-9.

[116] Perner S, Schmidt FH, Hofer MD, Kuefer R, Rubin M. [TMPRSS2-ETS gene fusion in prostate cancer]. Urologe A 2007; 46(7): 754-60.

[117] Tomlins SA, Mehra R, Rhodes DR, et al. TMPRSS2: ETV4 gene fusions define a third molecular subtype of prostate cancer. Cancer Res 2006; 66(7): 3396-400.

[118] Hermans KG, van Marion R, van Dekken H, Jenster G, van Weerden WM, Trapman J. TMPRSS2: ERG fusion by translocation or interstitial deletion is highly relevant in androgen-dependent prostate cancer, but is bypassed in late-stage androgen receptornegative prostate cancer. Cancer Res 2006; 66(22): 10658-63.

[119] Tu JJ, Rohan S, Kao J, Kitabayashi N, Mathew S, Chen YT. Gene fusions between TMPRSS2 and ETS family genes in prostate cancer: frequency and transcript variant analysis by RT-PCR and FISH on paraffin-embedded tissues. Mod Pathol 2007; 20(9): 921-8.

[120] Laxman B, Tomlins SA, Mehra R, et al. Noninvasive detection of TMPRSS2: ERG fusion transcripts in the urine of men with prostate cancer. Neoplasia 2006; 8(10): 885-8.

[121] Mosquera JM, Perner S, Demichelis F, et al. Morphological features of TMPRSS2-ERG gene fusion prostate cancer. J Pathol 2007; 212(1): 91-101.

[122] Ellinger J, Haan K, Heukamp LC, et al. CpG island hypermethylation in cell-free serum DNA identifies patients with localized prostate cancer. Prostate 2008; 68(1): 42-9.

[123] Li LC. Epigenetics of prostate cancer. Front Biosci 2007; 12: 3377 97.

[124] Costa VL, Henrique R, Jeronimo C. Epigenetic markers for molecular detection of prostate cancer. Dis Markers 2007; 23(1-2): 3141.

[125] Schulz WA, Hatina J. Epigenetics of prostate cancer: beyond DNA methylation. J Cell Mol Med 2006; 10(1): 100-25.

[126] Bastian PJ, Palapattu GS, Yegnasubramanian S, et al. CpG island hypermethylation profile in the serum of men with clinically localized and hormone refractory metastatic prostate cancer. J Urol 2008; 179(2): 529-34; discussion 34-5.

[127] Das PM, Singal R. DNA methylation and cancer. J Clin Oncol 2004; 22(22): 4632-42.

[128] Meiers I, Shanks JH, Bostwick DG. Glutathione S-transferase pi (GSTP1) hypermethylation in prostate cancer: review 2007. Pathology 2007; 39(3): 299-304.

[129] Woodson K, O'Reilly KJ, Hanson JC, Nelson D, Walk EL, Tangrea JA. The usefulness of the detection of GSTP1 methylation in urine 
as a biomarker in the diagnosis of prostate cancer. J Urol 2008; 179(2): 508-11; discussion 11-2.

[130] Hoque MO, Topaloglu O, Begum S, et al. Quantitative methylation-specific polymerase chain reaction gene patterns in urine sediment distinguish prostate cancer patients from control subjects. J Clin Oncol 2005; 23(27): 6569-75.

[131] Srivastava M, Montagna C, Leighton X, et al. Haploinsufficiency of Anx 7 tumor suppressor gene and consequent genomic instability promotes tumorigenesis in the Anx7(+/-) mouse. Proc Natl Acad Sci USA 2003; 100(24): 14287-92.

[132] Sun X, Frierson HF, Chen C, et al. Frequent somatic mutations of the transcription factor ATBF1 in human prostate cancer. Nat Genet 2005; 37(4): 407-12.

[133] Xu J, Sauvageot J, Ewing CM, et al. Germline ATBF1 mutations and prostate cancer risk. Prostate 2006; 66(10): 1082-5.

[134] Kibel AS, Suarez BK, Belani J, et al. CDKN1A and CDKN1B polymorphisms and risk of advanced prostate carcinoma. Cancer Res 2003; 63(9): 2033-6.

[135] Chang BL, Zheng SL, Isaacs SD, et al. A polymorphism in the CDKN1B gene is associated with increased risk of hereditary prostate cancer. Cancer Res 2004; 64(6): 1997-9.

[136] Wu X, Dong X, Liu W, Chen J. Characterization of CHEK2 mutations in prostate cancer. Hum Mutat 2006; 27(8): 742-7.

[137] Dong X, Wang L, Taniguchi K, et al. Mutations in CHEK2 associated with prostate cancer risk. Am J Hum Genet 2003; 72(2): 27080 .

[138] Ntais C, Polycarpou A, Ioannidis JP. Association of the CYP17 gene polymorphism with the risk of prostate cancer: a metaanalysis. Cancer Epidemiol Biomarkers Prev 2003; 12(2): 120-6.

[139] Chang BL, Zheng SL, Isaacs SD, et al. Polymorphisms in the CYP1B1 gene are associated with increased risk of prostate cancer. Br J Cancer 2003; 89(8): 1524-9.

[140] Rebbeck TR, Jaffe JM, Walker AH, Wein AJ, Malkowicz SB. Modification of clinical presentation of prostate tumors by a novel genetic variant in CYP3A4. J Natl Cancer Inst 1998; 90(16): 12259.

[141] Zeigler-Johnson C, Friebel T, Walker AH, et al. CYP3A4, CYP3A5, and CYP3A43 genotypes and haplotypes in the etiology and severity of prostate cancer. Cancer Res 2004; 64(22): 8461-7.
[142] Harries LW, Stubbins MJ, Forman D, Howard GC, Wolf CR. Identification of genetic polymorphisms at the glutathione S-transferase Pi locus and association with susceptibility to bladder, testicular and prostate cancer. Carcinogenesis 1997; 18(4): 641-4.

[143] Narla G, Difeo A, Reeves HL, et al. A germline DNA polymorphism enhances alternative splicing of the KLF6 tumor suppressor gene and is associated with increased prostate cancer risk. Cancer Res 2005; 65(4): 1213-22.

[144] Chen C, Hyytinen ER, Sun X, et al. Deletion, mutation, and loss of expression of KLF6 in human prostate cancer. Am J Pathol 2003; 162(4): 1349-54.

[145] Suzuki H, Freije D, Nusskern DR, et al. Interfocal heterogeneity of PTEN/MMAC1 gene alterations in multiple metastatic prostate cancer tissues. Cancer Res 1998; 58(2): 204-9.

[146] Dong JT, Li CL, Sipe TW, Frierson HF, Jr. Mutations of PTEN/MMAC1 in primary prostate cancers from Chinese patients. Clin Cancer Res 2001; 7(2): 304-8.

[147] Whang YE, Wu X, Suzuki H, et al. Inactivation of the tumor suppressor PTEN/MMAC1 in advanced human prostate cancer through loss of expression. Proc Natl Acad Sci USA 1998; 95(9): 5246-50.

[148] Bhatia-Gaur R, Donjacour AA, Sciavolino PJ, et al. Roles for Nkx3.1 in prostate development and cancer. Genes Dev 1999; 13(8): 966-77.

[149] Asatiani E, Huang WX, Wang A, et al. Deletion, methylation, and expression of the NKX3.1 suppressor gene in primary human prostate cancer. Cancer Res 2005; 65(4): 1164-73.

[150] Bowen C, Bubendorf L, Voeller HJ, et al. Loss of NKX3.1 expression in human prostate cancers correlates with tumor progression. Cancer Res 2000; 60(21): 6111-5.

[151] Voeller HJ, Augustus M, Madike V, Bova GS, Carter KC, Gelmann EP. Coding region of NKX3.1, a prostate-specific homeobox gene on $8 \mathrm{p} 21$, is not mutated in human prostate cancers. Cancer Res 1997; 57(20): 4455-9.

[152] Zheng SL, Ju JH, Chang BL, et al. Germ-line mutation of NKX3.1 cosegregates with hereditary prostate cancer and alters the homeodomain structure and function. Cancer Res 2006; 66(1): 69-77. 